\title{
Pengembangan Media Pembelajaran Berbasis Multimedia Interaktif dalam Pelajaran Hukum Tajwid
}

\author{
Athiyyah Fudlla 'Aini, Herlambang Saputra, Isnainy Azro \\ Program Studi Teknologi Informatika Multimedia Digital, Jurusan Teknik Komputer, \\ Politeknik Negeri Sriwijaya \\ Jl. Srijaya Negara, Bukit Lama, Bukit Besar, Kota Palembang, Sumatera Selatan, Telp: (0711)353414/Fax: \\ $+62711355918$ \\ afaaini99@gmail.com, herlambang@polsri.ac.id, adamputra.azro@gmail.com
}

Diterima : 27 November 2020. Disetujui : 12 Maret 2021. Dipublikasikan : 12 Maret 2021.

\begin{abstract}
Indonesia is a country with a majority muslim population. So that the science of religion needs to be taught from an early age, for example is the science of Tajweed. Recently, the development of technology in Indonesia has been very fast, but interactive religious learning using electronic media is currently still few especially interactive learning media with the theme of Tajweed learning. For this reason, the author has a goal to develop a legal learning media application for Tajweed to make it easier for children and parents to learn (hukum tajwid) wherever and whenever. In this learning media, distribution efforts are made by making an application that can be installed on an Android smartphone. So that it is easier to access and use by the community. In addition, research is carried out on the success of this learning media through 2 aspects, namely aspects of the attractiveness and quality of learning media which are assessed by experts in the field of animation/learning media, as well as aspects of the quality of the content of learning media judged by the community. The approach in this research is quantitative with descriptive research type. The method used in this research is a survei method using a questionnaire technique. Respondents in this study were 4 expert respondents and 40 community members, which were obtained from distributing online questionnaires. The results of this study show that the attitudes of 4 expert respondents regarding this Learning Media are 81 $\% \%$ and are in the "Very Good" category and the attitudes of 40 general public respondents are $93.7 \%$ and are in the "Very Good" category.
\end{abstract}

Keywords: learning media, interactive multimedia, tajweed lessons.

\begin{abstract}
Abstrak - Indonesia merupakan sebuah negara dengan mayoritas penduduk muslim, sehingga ilmu agama perlu diajarkan sejak dini contohnya Ilmu Tajwid. Saat ini perkembangan teknologi di Indonesia sangatlah pesat, namun pembelajaran ilmu agama yang interaktif menggunakan media-media elektronik saat ini masih sedikit ditemui khususnya media pebelajaran interaktif yang bertemakan pembelajaran ilmu tajwid. Untuk itu penulis bertujuan mengembangkan sabuah aplikasi media pembelajaran hukum tajwid untuk memudahkan anak-anak dan orang tua untuk belajar (hukum tajwid) dimanapun dan kapanpun. Pada media pembelajaran ini, upaya pendistribusian dilakukan dengan cara dijadikan sebuah aplikasi yang bisa di install pada smartphone android sehingga lebih mudah di akses dan digunakan oleh masyarakat. Selain itu juga dilakukan penelitian terhadap keberhasilan media pembelajaran ini melalui 2 aspek, yaitu aspek daya tarik dan kualitas media pembelajaran yang dinilai oleh para ahli bidang animasi/media pembelajaran, serta aspek kualitas isi materi media pembelajaran yang dinilai oleh masyarakat. Pendekatan dalam penelitian ini adalah kuantitatif dengan jenis penelitian deskriptif. Metode yang digunakan dalam penelitian ini adalah metode survei dengan menggunakan teknik kuesioner. Responden dalam penelitian ini berjumlah 4 orang responden ahli dan 40 orang masyarakat, yang didapatkan dari penyebaran kuesioner online. Hasil dari penelitian ini diketahui bahwa sikap 4 orang responden ahli mengenai Media Pembelajaran ini sebesar 81\% dan berada di kategori "Sangat Baik" dan sikap 40 orang responden masyarakat umum sebesar $93,7 \%$ dan berada di kategori "Sangat Baik".
\end{abstract}

Kata kunci: media pembelajaran, multimedia interaktif, pelajaran hukum tajwid.

\section{PENDAHULUAN}

Indonesia merupakan salah satu Negara dengan penduduk mayoritas beragama Islam terbanyak di dunia. Sehingga banyak pelajaran tentang keagamaan yang mulai di ajarkan kepada anak-anak sejak usia dini. Salah satu pelajaran yang paling penting adalah belajar ilmu tajwid yang menjadi panduan untuk membaca Al-qur'an dengan baik dan benar. Tajwid secara teori adalah fardhu kifayah, sedangkan hukum membaca Al-qur'an sesuai dengan kaidah ilmu tajwid adalah fardhu 'ain[1]. Pembelajaran ilmu tajwid sangat penting dilakukan mulai usia dini, karena dimasa kanakkanak biasanya lebih mudah untuk mempelajari tentang ilmu tajwid. Pemahaman tentang pembelajaran ilmu tajwid perlu diterapkan kepada 
anak-anak khusunya yang sedang menempuh sekolah baik formal maupun non-formal seperti TPA dan TQA.

Survei yang dilakukan oleh Institut Ilmu AlQur'an (IIQ) Jakarta pada tahun 2011 menyebutkan bahwa $65 \%$ umat Islam Indonesia buta aksara AlQur'an, 35\% hanya dapat membaca Al-Qur'an saja sedangkan yang mampu membaca dengan benar hanya 20\%. Sedangkan survei yang dilakukan oleh lembaga Survei Sosial Ekonomi Nasional (SUSENAS) 2013 Badan Pusat Statistik (BPS) mengemukakan bahwa $53,8 \%$ ummat Islam Indonesia tidak dapat membaca Al-Qur'an[2].

Permasalahan-permasalahan yang teridentifikasi dan sering muncul dalam pembelajaran Al-qur'an adalah tidak konsistennya penggunaan hukum dalam membaca Al-qur'an[3] dan metode penyampaian materi yang masih kurang membuat sistem pembelajaran yang ada menjadi membosankan untuk dipelajari. Apalagi saat ini, teknologi mulai berkembang dan anak-anak tidak bisa dijauhkan dari teknologi. Terkadang anak-anak lebih memilih untuk memainkan gadget seharian dibandingkan belajar ilmu agama. Selain itu dengan adanya program full day school anak-anak hanya mempunyai sedikit waktu untuk belajar tajwid ke TPA/TPQ. Tak hanya anak-anak bahkan orang tua pun juga memiliki masalah yang sama, kesibukan orang tua untuk bekerja mengurangi intensitas waktu untuk belajar ilmu agama. Sehingga diperlukan sebuah media pembelajaran yang bisa digunakan kapanpun dan dimanapun.

Pembelajaran ilmu agama yang interaktif menggunakan media-media elektronik saat ini masih sedikit ditemui, khususnya media pebelajaran interaktif yang bertemakan pembelajaran ilmu tajwid. Anak-anak masih merasa kesulitan untuk membaca Al-qur'an, sehingga perlu pembelajaran lebih untuk membuat anak lebih tertarik untuk belajar ilmu tajwid. Maka dari itu di butuhkan sebuah inovasi baru mengenai media pembelajaran elektronik berbasis multimedia yang bisa di fungsikan untuk belajar ilmu tajwid bagi anak-anak dengan konsep yang tidak membosankan namun tetap sarat akan pengetahuan.

Media pembelajaran adalah segala sesuatu yang dapat menyalurkan pesan, dapat merangsang fikiran, perasaan, dan kemauan peserta didik sehingga dapat mendorong terciptanya proses belajar pada diri peserta didik[4]. Media pembelajaran sendiri meliputi alat yang secara fisik digunakan untuk menyampaikan isi materi pengajaran, yang terdiri antara lain buku, tape recorder, televisi, komputer, dan lainnya. Di era kecanggihan teknologi saat ini, media pembelajaran sudah banyak dikembangkan salah satunya menjadi media pembelajaran interaktif berbasis multimedia.

Pembelajaran dengan multimedia merupakan gabungan dari berbagai macam media yang terintegrasi yang secara bersama-sama menampilkan informasi, pesan, atau isi pelajaran[5]. Multimedia pembelajaran juga bisa diartikan berbagai bentuk media yang digunakan untuk menyajikan suatu informasi secara berurutan maupun simultan melalui komputer.

Berdasarkan uraian diatas, maka judul yang diambil penulis pada penelitian ini adalah Pengembangan Media Pembelajaran Berbasis Multimedia Interaktif dalam Pelajaran Hukum Tajwid.

Masalah yang akan dikaji dalam penelitian ini adalah bagaimana pengembangan media pembelajaran berbasis multimedia interaktif dalam pelajaran hukum tajwid serta bagaimana analisis data terhadap pengujian dari media pembelajaran tersebut. Masalah yang di bahas dibatasi dengan pembuatan media pembelajaran menggunakan perangkat lunak 2 dimensi (2D) dan materi yang akan di bahas di dalamnya merupakan Hukum Tajwid menggunakan Metode Asy-syafi'i. Metode Asy-syafi'i merupakan salah satu metode yang digunakan untuk membantu dalam mempelajari dan memperbaiki bacaan Al-qur'an. Pelajaran yang dibahas di dalamnya diantaranya iqra' atau belajar membaca Al-qur'an, ilmu tajwid dan pendalaman tajwid[6].

Tujuan dari penelitian ini adalah membuat inovasi baru mengenai pembelajaran hukum tajwid dengan media pembelajaran berbasis multimedia, mengembangkan pembelajaran hukum tajwid menggunakan media pembelajaran berbasis multimedia interaktif, dan memanfaatkan media digital untuk membuat media pembelajaran yang lebih efektif dan menarik.

Manfaat yang diharapkan dari penelitian ini adalah terciptanya media pembelajaran hukum tajwid yang menarik untuk di pelajari bagi masyarakat, memudahkan masyarakat untuk belajar tajwid dengan cara yang menyenangkan dan tidak membosankan, serta dapat digunakan kapanpun dan dimanapun.

\section{TINJAUAN PUSTAKA}

\section{A. Media Pembelajaran Multimedia Interaktif}

Media pembelajaran adalah alat, metode, dan teknik yang digunakan dalam rangka lebih mengefektifkan komunikasi dan interaksi antara guru dan siswa dalam proses pendidikan dan pengajaran di sekolah. Suprapto dkk menyatakan bahwa media pembelajaran adalah suatu alat pembantu secara efektif yang dapat digunakan oleh 
guru untuk mencapai tujuan yang diinginkan. Sedangkan Yudhi Munadi mendefinisikan "media pembelajaran adalah segala sesuatu yang dapat menyampaikan dan menyalurkan pesan dari sumber secara terencana sehingga tercipta lingkungan belajar yang kondusif di mana penerimanya dapat melakukan proses belajar secara efisien dan efektif'[7]. Sesuai pendapat-pendapat tersebut dapat disimpulkan media pembelajaran merupakan alat yang digunakan untuk menyalurkan pesan dari sumber belajar yaitu buku atau modul dan sumber belajar lainnya kepada penerima yaitu siswa, agar tercipta lingkungan berlajar yang kondusif, efisien, dan menyenangkan.

Multimedia interaktif merupakan suatu alat yang di lengkapi dengan alat kontrol yang dapat dioperasikan oleh penggunanya dalam memilih sesuatu yang dikehendaki. Contoh multimedia interaktif adalah : multimedia pembelajaran interaktif (pembelajaran berbasis multimedia interaktif), aplikasi game dan lain-lain[8].

\section{B. Tajwid}

Ilmu tajwid merupakan salah satu ilmu yang paling utama yang perlu dimiliki dan dipelajari oleh seorang muslim sejak masih anak-anak, yaitu dengan membaca Al-quran dengan baik dan benar. Hal ini sangat penting karena didalam agama islam hukum mempelajari serta mengamalkan Al-quran adalah fardhu 'ain yang artinya menjadi prioritas yang paling diutamakan sebelum belajar dari ilmuilmu pengetahuan lainnya. Baik dan benarnya bacaan Al-quran merupakan salah satu syarat kesempurnaan ibadah shalat seorang muslim dan muslimah[9].

Secara etimologi, kata tajwid merupakan bentuk mashdar dari kata jawwada yang berarti memperbaiki/memperindah (at-Taḥsin). Sedangkan menurut terminologi, tajwid dalam Bahasa Arab adalah:

الصفات

$$
\text { آخر اج كل حرف من مخروجه و اعطاءه حقه ومستحقه من }
$$

Artinya : "Mengucapkan setiap huruf dari tempat keluarnya serta memberikan haq dan mustahaq dari sifat-sifatnya"[10]

Menurut al-Suyuți, tajwid adalah hiasan bacaan, yaitu memberikan kepada setiap huruf hakhaknya dan urutan-urutannya serta mengembalikan setiap huruf kepada makhraj dan asalnya, melunakkan pengucapan dengan keadaan yang sempurna, tanpa berlebih-lebihan dan memaksakan diri. Urgensi pembacaan Al-quran dengan tajwid dapat dilihat dari beberapa aspek, yaitu, pertama, adanya riwayat yang memerintahkan untuk membaca Al-quran dengan tajwid, sebagaimana yang dikutip oleh al-Suyuti dalam kitab al-Dāni bahwa ibn Mas'ud berkata: "Bacalah Al-quran dengan tajwid". Kedua, menjaga lidah dari laḥn (kesalahan) ketika membaca Al-quran sebab ulama menganggap bacaan tanpa tajwid sebagai lahn (kesalahan)[11].

\section{Teknologi yang Digunakan}

Pada pembuatan media pembelajaran berbasis multimedia interaktif memerlukan berbagai alat teknologi dalam menunjang proses produksi. Teknologi yang digunakan dalam bentuk hardware yaitu laptop dengan spesifikasi RAM 4 GB AM Radeon R5 Graphics, HDD 500 GB, OS Windows 10, mouse, dan smartphone sebagai alat perekam suara. Sedangkan software yang digunakan ialah software desain animasi 2D.

\section{METODE PENELITIAN}

Proses pembuatan media pembelajaran ini dimulai dengan membuat proses perancangan, pembuatan hingga analisis hasil pengujian. Perancangan dalam penelitian ini adalah berupa perancangan media pembelajaran dan perancangan kuesioner. Dari perancangan media pembelajaran dan perancangan kuesioner tersebut, dapat diketahui solusi dari permasalahan yang ada. Dalam perancangan media pembelajaran berbasis multimedia interaktif pada hukum Tajwid ini terdapat tiga tahapan, yaitu praproduksi, produksi, dan pascaproduksi. Selain itu, perancangan media pembelajaran ini merujuk pada suatu metode pengembangan yaitu metode pengembangan Multimedia Luther. Proses perancangan media pembelajaran ini akan dijelaskan pada Gambar 1 berikut:

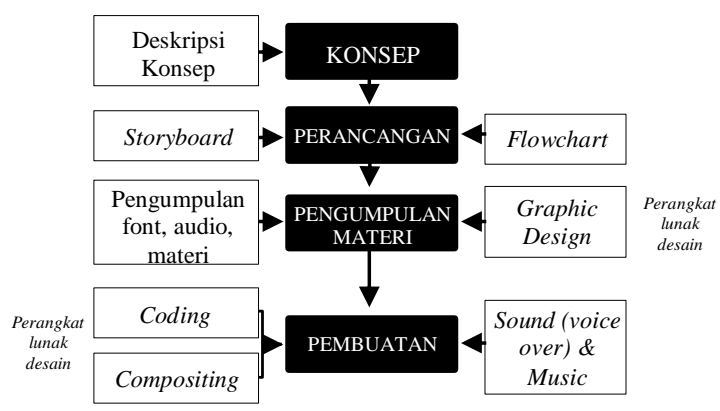

Gambar 1. Bagan Perancangan

Menurut Luther, pengembangan multimedia dapat dilakukan dengan metode Multimedia Development Life Cycle (MDLC)[12], yaitu:

1. Konsep (Concept)

Merumuskan dasar-dasar dari proyek media pembelajaran yang akan dibuat dan dikembangkan. Terutama pada tujuan dan jenis proyek yang akan dibuat. 
2. Desain (Design)

Tahap pembuat atau pengembang proyek multimedia menjabarkan secara rinci apa yang akan dilakukan dan bagaimana proyek multimedia tersebut akan dibuat.

3. Pengumpulan Materi (Material Collecting)

Pengumpulan materi merupakan proses untuk pengumpulan segala sesuatu yang dibutuhkan dalam proyek.

4. Pembuatan (Assembly)

Waktunya proyek media pembelajaran diproduksi. Materi-materi serta file-file multimedia yang sudah didapat kemudian dirangkai dan disusun sesuai desain.

\section{A. Perancangan Media Pembelajaran}

Secara garis besar, proses perancangan media pembelajaran dibagi menjadi beberapa tahap sebagai berikut:

> Praproduksi, meliputi poin konsep dan perancangan. Yang dilakukan pada tahap ini adalah membuat deskripsi konsep, storyboard dan flowchart media pembelajaran.

> Produksi, meliputi poin: pengumpulan materi (audio dan graphic design). Tahapan ini dimulai dengan pembuatan background untuk media pembelajaran serta ikon-ikon yang akan digunakan sebagai tombol dalam media pembelajaran. Selain itu, pada tahap ini juga dilakukan proses voice recording sebagai pengisi suara pada media pembelajaran.

$>$ Pascaproduksi, meliputi poin pembuatan (compositing, coding dan penambahan sound effect). Pada tahap ini dilakukan dengan menyatukan semua yang sudah di kerjakan dalam proses produksi. Selain itu juga dilakukan pembuatan script agar media pembelajaran dapat berjalan dengan baik.

Semua dilakukan secara bertahap dan sesuai dengan penjadwalan. Proses produksi harus diatur secara saksama agar tidak ada proses yang terlewatkan. Satu proses saja dilewatkan akan berdampak buruk dalam manajemen produksi yang mengakibatkan penambahan jadwal produksi.

\section{Deskripsi Konsep}

Tabel I berikut ini merupakan deskripsi dari konsep media pembelajaran berbasis multimedia interaktif yang akan penulis buat.
TABEL I. DESKRIPSI KONSEP

\begin{tabular}{ll}
\hline Judul & $\begin{array}{l}\text { Belajar tajwid "Metode Asy- } \\
\text { syafi'I" }\end{array}$ \\
\hline $\begin{array}{l}\text { Jenis Media } \\
\text { Pembelajaran }\end{array}$ & $\begin{array}{l}\text { Media Pembelajaran Berbasis } \\
\text { Multimedia Interaktif }\end{array}$ \\
\hline Target Audiens & $\begin{array}{l}\text { Semua umur khususnya yang baru } \\
\text { belajar hukum tajwid }\end{array}$ \\
\hline $\begin{array}{l}\text { Metode dari materi } \\
\text { yang digunakan }\end{array}$ & $\begin{array}{l}\text { Pelajaran Tajwid Metode Asy- } \\
\text { syafi'i }\end{array}$ \\
\hline
\end{tabular}

\section{Storyboard}

Pada Tabel II berikut merupakan rancangan storyboard yang akan digunakan pada tahap pra produksi dari media pembelajaran berbasis multimedia interaktif pada pelajaran hukum tajwid.

TABEL II. STORYBOARD

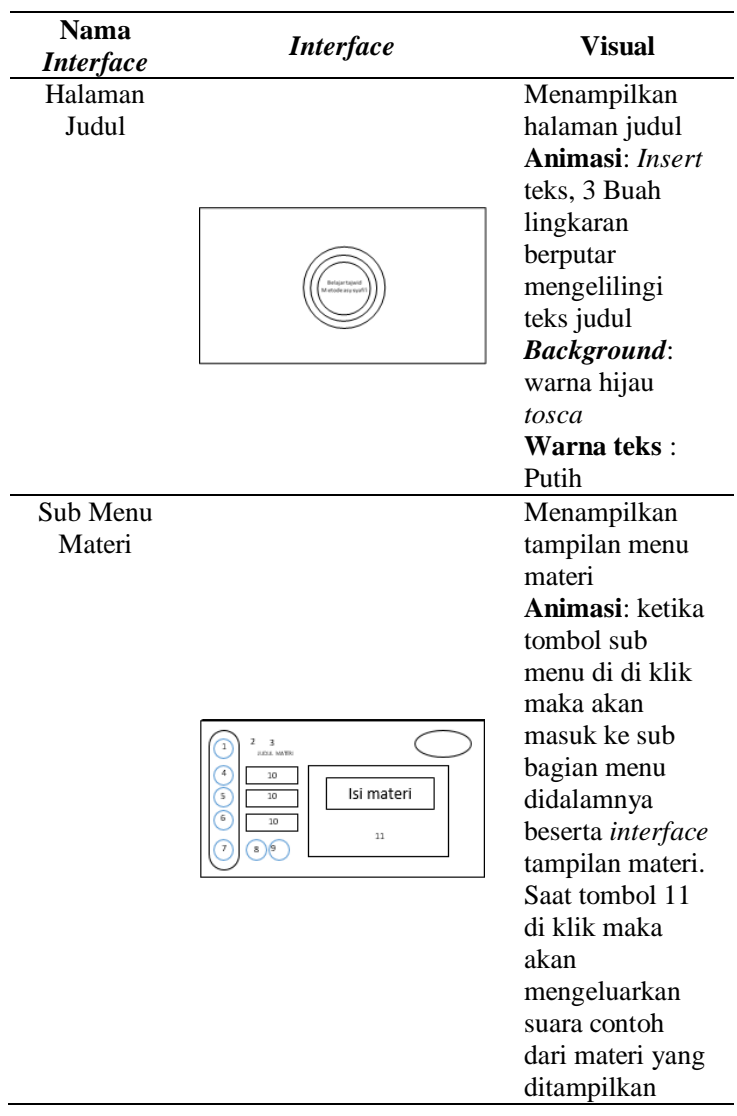

\section{Flowchart}

Flowchart adalah penggambaran secara grafik dari langkah-langkah dan urutan-urutan prosedur dari suatu program. Flowchart menolong analyst dan programmer untuk memecahkan masalah ke dalam segmen-segmen yang lebih kecil dan menolong dalam menganalisis alternatifalternatif lain dalam pengoperasian[13]. Gambar 2 berikut ini merupakan flowchart dari media pembelajaran interaktif yang dibuat oleh penulis. 


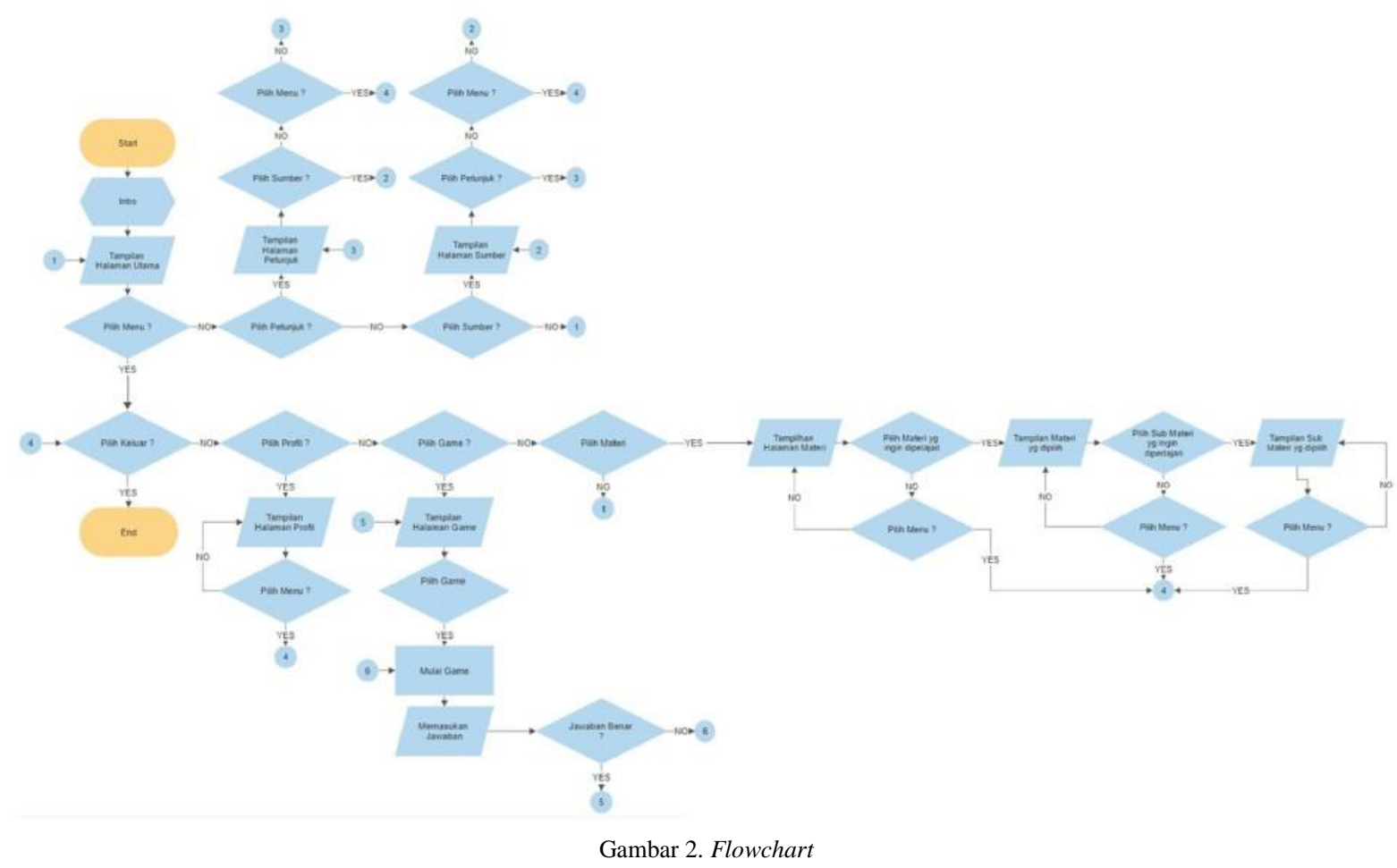

4. Pengumpulan Materi

Pada tahap ini pengumpulan bahan-bahan berupa file gambar background, gambar button, file gambar berupa logo Politeknik Negeri Sriwijaya, logo Program Studi Teknologi Informatika Multimedia Digital, file font, serta file-file audio berupa sound effect dan musik instrumen. Untuk pembuatan Background dan button penulis menggunakan software desain digital.

- Materi yang dibahas

Referensi materi yang digunakan penulis dalm pembuatan media pembelajaran adalah buku belajar hukum tajwid dengan judul "Metode Asy-syafi'i Ilmu Tajwid Praktis 20 Jam" yang ditulis oleh Abu Ya'la Kurnaedi, Lc dan Nizar Sa'ad Jabal, Lc. M.P dengan editor ahli Abul Afnan Aiman Abdillah, Lc. Delain mengambil referensi dari buku tersebut, pemateri juga berkonsultasi langsung dengan narasumber yang berkompeten di bidang ilmu tajwid yaitu Ibu Ema Sofiana Wahab, S.Ag., M.Pdi.

- Desain

Pembuatan desain dilakukan dengan menggunakan Software desain digital. Contoh desain yang dibuat penulis ditampilkan pada Gambar 3 berikut:
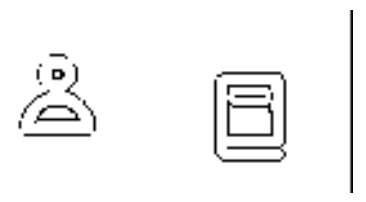

Gambar 3. Ikon button Profil dan Materi

- Rekaman suara

Rekaman suara digunakan sebagai voice over pada saat contoh materi diklik. Pada proses rekaman suara untuk voice over, penulis menggunakan aplikasi voice recorder yang terdapat pada smartphone berjenis Xiaomi Redmi 4X. Format file recorder pada aplikasi ini adalah *mp3.

- Pengumpulan materi tambahan

Selain pembuatan desain dan rekaman suara voice over, penulis juga menggunakan materi tambahan lain berupa file font, gambar, dan musik. Beberapa dari file tersebut penulis dapatkan dengan cara mengunduh dari beberapa situs internet. Tabel III dan Tabel IV merupakan beberapa contoh materi yang digunakan pada pembuatan media pembelajaran ini:

TABEL III. BEBERAPA CONTOH MATERI AUDIO

\begin{tabular}{cccc}
\hline No. & Nama File & $\begin{array}{c}\text { Format } \\
\text { File }\end{array}$ & Keterangan \\
\hline 1 & $\begin{array}{l}\text { Melody of } \\
\text { Happiness }\end{array}$ & $\mathrm{mp} 4$ & Backsound \\
\hline 2 & $\begin{array}{l}\text { Hawaiian } \\
\text { Weekend }\end{array}$ & $\mathrm{mp} 4$ & Backsound \\
\hline
\end{tabular}


TABEL IV. BEBERAPA CONTOH MATERI GAMBAR

No \begin{tabular}{ccc}
\hline Nama File & $\begin{array}{c}\text { Format } \\
\text { file }\end{array}$ \\
\hline & Logo Polsri & png \\
2. & $\begin{array}{c}\text { Logo Program } \\
\text { Studi } \\
\text { Teknologi } \\
\text { Informatika } \\
\text { Multimedia } \\
\text { Digital }\end{array}$ & png
\end{tabular}

5. Pengomposisian (compositing)

Pada tahap ini dilakukan dengan menyatukan semua yang sudah di kerjakan dalam proses produksi. Baik dari segi desain, audio maupun script.

\section{B. Perancangan Kuesioner}

Penelitian ini mengambil sampel sebanyak 4 orang responden ahli (alfa) dan 40 orang responden dari masyarakat umum (beta) dengan menggunakan teknik angket kuesioner. Kuesioner merupakan sekumpulan pertanyaan yang digunakan untuk memperole informasi dari responden terkait dengan pribadinya maupun hal-hal lain yang terkait dengan materi penelitian[14]. Variabel yang digunakan adalah kualitas isi materi media pembelajaran, daya tarik media pembelajaran yang dilhat dari segi tampilan. Respon pengujian di tujukan untuk memberikan kesimpulan bahwa hasil media pembelajaran sesuai dengan tujuan pembuatan.

Selain mengajukan pertanyaan tentang data penilaian media pembelajaran dari segi isi materi dan data dari segi tampilan, kuesioner juga dilakukan untuk mengumpulkan biodata responden. Data yang diambil dalam biodata responden adalah nama, umur, dan pekerjaan.

\section{Kuesioner Alfa (ahli)}

Kuesioner alfa adalah kuesioner yang diberikan kepada para ahli di bidang multimedia dan animasi[12]. Tujuan dari kuesioner alfa adalah untuk mengetahui kelayakan dari media pembelajaran berbasis multimedia interaktif yang telah dibuat untuk digunakan. Penilaian yang dilakukan pada kuesioner ini yaitu dari segi tampilan pada media pembelajaran, dan respon dari tombol yang ada. Terdapat 5 item pilihan jawaban yang dapat dipilih responden yaitu SKB (Sangat Kurang Baik), KB (Kurang Baik), C (Cukup), B (Baik), SB (Sangat Baik). Selain itu, aspek yang diajukan dalam mewakili kriteria dari segi tampilan terdapat 6 aspek penilaian dan kolom saran. Aspek tersebut seperti yang terdapat pada Tabel V berikut.
TABEL V. PERTANYAAN KUESIONER ALFA

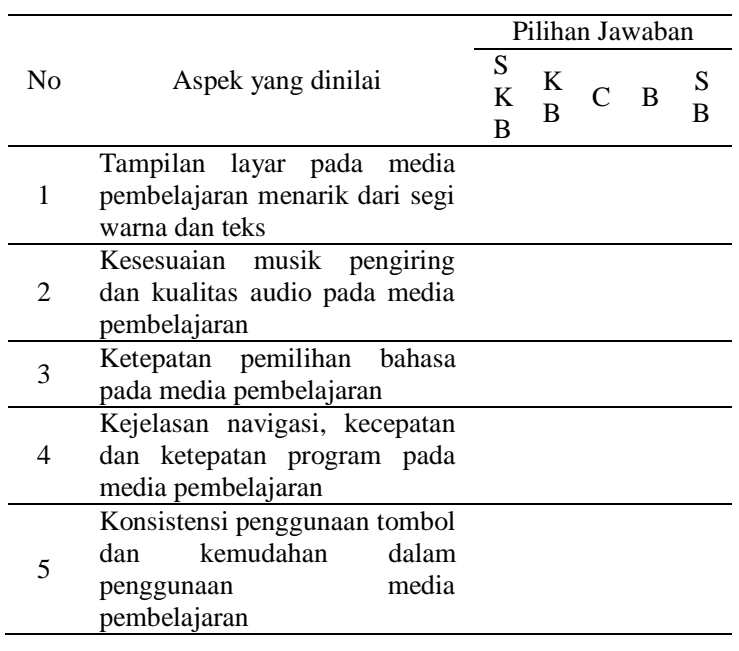

\section{Kuesioner Beta}

Kuesioner beta adalah kuesioner yang diberikan kepada masyarakat umum yang berumur $\geq$ 14 tahun. Tujuan dari kuesioner beta adalah untuk mengetahui kualitas dari materi yang disampaikan pada media pembelajaran berbasis multimedia interaktif serta kemenarikan media pembelajaran dari segi tampilan. Kualitas materi digunakan untuk mengetahui apakah informasi yang disampaikan dapat dipahami dengan baik atau tidak serta apakah dapat membuat masyarakat menjadi lebih mengetahuinya atau tidak. Penilaian yang dilakukan pada kuesioner ini yaitu dari segi kualitas materi media pembelajaran dan dari segi tampilan media pembelajaran. Terdapat 5 item pilihan jawaban yang dapat dipilih responden yaitu SKB (Sangat Kurang Baik), KB (Kurang Baik), C (Cukup), B (Baik), SB (Sangat Baik). Aspek pada masing-masing kriteria dapat dilihat pada Tabel VI berikut ini.

TABEL VI. . PERTANYAAN KUESIONER BETA

\begin{tabular}{|c|c|c|c|c|c|c|}
\hline \multirow[b]{2}{*}{ No } & \multirow[b]{2}{*}{ Aspek yang dinilai } & \multicolumn{5}{|c|}{ Pilihan Jawaban } \\
\hline & & & $\begin{array}{l}\mathrm{K} \\
\mathrm{B}\end{array}$ & $\mathrm{C}$ & B & $\begin{array}{l}\text { S } \\
\text { B }\end{array}$ \\
\hline 1 & $\begin{array}{l}\text { Tampilan layar pada media } \\
\text { pembelajaran menarik dari segi } \\
\text { warna dan teks }\end{array}$ & & & & & \\
\hline 2 & $\begin{array}{l}\text { Kesesuaian musik pengiring } \\
\text { dan kualitas audio pada media } \\
\text { pembelajaran }\end{array}$ & & & & & \\
\hline 3 & $\begin{array}{l}\text { Kejelasan uraian materi dan } \\
\text { pemberian contoh pada media } \\
\text { pembelajaran }\end{array}$ & & & & & \\
\hline 4 & $\begin{array}{l}\text { Setelah menggunakan media } \\
\text { pembelajaran ini anda } \\
\text { mengetahui tentang hukum- } \\
\text { hukum tajwid }\end{array}$ & & & & & \\
\hline 5 & $\begin{array}{l}\text { Materi yang di sampaikan pada } \\
\text { media pembelajaran ini mudah } \\
\text { di pahami }\end{array}$ & & & & & \\
\hline
\end{tabular}




\section{Tes Kinerja Sistem}

Tes kinerja sistem dilakukan dengan cara penilaian dari ahli materi, pengujian terhadap responden ahli (alfa) dan pengujian terhadap responden masyarakat umum (beta). Pengujian ini dilakukan dengan cara yang sama, yang membedakan adalah objek penelitian. Pada pengujian terhadap responden, dilakukan sosialisasi kepada masyarakat dengan cara mengirim link untuk mengunduh media pembelajaran yang telah dibuat.

Setelah dilakukan sosialisasi, tahapan yang akan dilakukan adalah mengolah data dan menganalisa data hasil sosialisasi tersebut untuk mengetahui tingkat keberhasilan media pembelajaran yang dibuat. Respon pengujian di tujukan untuk memberikan kesimpulan bahwa media pembelajaran ini layak atau tidak untuk gunakan dan dipublikasikan. Pengujian dilakukan dengan cara menyebarkan kuesioner menggunakan kuesioner online (google form). Analisis data yang akan dilakukan menggunakan metode perhitungan dengan Skala Likert. Skala Likert merupakan metode skala bipolar yang mengukur baik tanggapan positif ataupun negatif terhadap suatu pernyataan[15]. Terdapat 5 item pilihan jawaban pada kuesioner, nilai setiap item yang merupakan hasil dari pilihan responden akan dikalkulasikan dengan bobot setiap item pilihan.

\section{Penentuan skor jawaban}

Hal pertama yang harus dilakukan adalah menentukan skor dari tiap jawaban yang akan diberikan. Skor jawaban atau disebut juga nilai skala telah ditentukan sesuai dengan aturan metode skala likert. Tabel VII berikut ini merupakan pembagian skor nilai untuk setiap poin jawaban sesuai dengan peraturan skala likert.

\section{TABEL VII. NILAI SKALA $\left(\boldsymbol{N}_{\boldsymbol{s}}\right)$}

\begin{tabular}{cc}
\hline Item Jawaban (I) & Nilai Skala $\left(\boldsymbol{N}_{\boldsymbol{s}}\right)$ \\
\hline SB (Sangat Baik) & 5 \\
\hline B (Baik) & 4 \\
\hline C (Cukup) & 3 \\
\hline KB (Kurang Baik) & 2 \\
\hline SKB (Sangat Kurang Baik) & 1 \\
\hline
\end{tabular}

\section{Skor Ideal (Kriterium)}

Skor ideal digunakan untuk menentukan rating scale dan jumlah seluruh jawaban. Untuk menghitung jumlah skor ideal (kriterium) dari seluruh item, digunakan rumus berikut, yaitu:

$$
\mathrm{K}=N_{s} \times \mathrm{J}
$$

Keterangan:

K : Skor Kriterium

$N_{S}:$ Nilai Skala

J : Total Responden
Seandainya skor tertinggi adalah 5 dan jumlah responden 20, maka dapat dirumuskan menjadi:

TABEL VIII. . SKOR KRITERIUM (IDEAL)

\begin{tabular}{cc}
\hline Skor Kriterium $(\mathbf{K})$ & Skala \\
\hline $5 \times 20=100$ & SB \\
\hline $4 \times 20=80$ & B \\
\hline $3 \times 20=60$ & C \\
\hline $2 \times 20=40$ & KB \\
\hline $1 \times 20=20$ & SKB \\
\hline
\end{tabular}

Selanjutnya semua jawaban responden dijumlahkan dan dimasukkan ke dalam rating scale dan ditentukan daerah jawabannya.

6. Rating Scale

Selanjutnya, menentukan interval (I) yang akan digunakan sebagai interval antarskala. Lihat rumus dibawah ini.

$$
I=\frac{100 \%}{\text { Jumlah Skor Likert }}
$$

$I=\frac{100 \%}{5}$

$I=20 \%$

Keterangan: $\mathrm{I}=$ Interval

Skor yang telah diperoleh kemudian dimasukkan ke dalam rating scale.

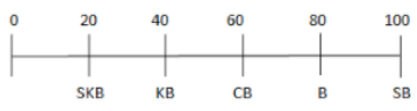

Gambar 4. Rating Scale

Rating scale berfungi untuk mengetahui hasil data angket (kuesioner) secara umum dan keseluruhan yang didapat dari penilaian angket (kuesioner). Dengan ketentuan seperti Tabel IX berikut.

TABEL IX. RATING SCALE

\begin{tabular}{cc}
\hline Nilai Jawaban & Skala \\
\hline Angka $80 \%-100 \%$ & SB \\
\hline Angka $60 \%-79,99 \%$ & B \\
\hline Angka $40 \%-59,99 \%$ & C \\
\hline Angka $20 \%-39,99 \%$ & KB \\
\hline Angka $0 \%-19,99 \%$ & SKB \\
\hline
\end{tabular}

7. Persentase Persetujuan

Persentase persetujuan disebut juga $R \_i$ atau Rumus Indeks. Untuk mengetahui jumlah jawaban dari para responden melalui persentase, yaitu digunakan rumus sebagai berikut: 


$$
R_{i}=\frac{\text { Total Skor }}{\mathrm{Y}} \times 100 \%
$$

Keterangan:

$R_{i} \quad$ : Rumus Indeks

$\mathrm{Y} \quad$ : Skor Tertinggi

100 : Bilangan tetap Namun,

Namun, sebelum menentukan nilai dari Total Skor dan Y, langkah pertama yang harus dilakukan adalah menentukan nilai jawaban dari masingmasing item (I) dengan cara berikut ini:

$$
I_{n}=x_{n} \times B
$$

Keterangan:

$I_{n} \quad$ : Nilai dari jawaban setiap pilihan

$x_{n}$ : Jumlah responden yang memilih pilihan jawaban

$B$ : Bobot nilai skor likert dalam pilihan jawaban

Langkah kedua tentukan nilai total dari jawaban semua item (Total Skor) dengan cara berikut ini:

$$
\text { Total Skor }=I_{s k}+I_{k}+I_{c}+I_{b}+I_{s b}
$$

Keterangan:

$I_{s k} \quad$ : Jumlah responden yang memilih jawaban Sangat Kurang

$I_{k} \quad$ : Jumlah responden yang memilih jawaban Kurang

$I_{c} \quad$ : Jumlah responden yang memilih jawaban Cukup

$I_{b} \quad$ : Jumlah responden yang memilih jawaban Baik

$I_{s b} \quad$ : Jumlah responden yang memilih jawaban Sangat Baik

Langkah selanjutnya yaitu menentukan jumlah skor tertinggi (Y) dengan cara berikut ini:

$$
\mathrm{Y}=\mathrm{T}_{t} \times \mathrm{J}
$$

Keterangan:

Y : Jumlah skor tertinggi

$\mathrm{T}_{t}$ : Skor tertinggi likert (5)

$\mathrm{J}$ : Jumlah semua responden

\section{HASIL DAN PEMBAHASAN}

\section{A. Hasil}

Setelah selesai melakukan serangkaian tahap perancangan, maka akan didapat hasil aplikasi dengan format *apk. Aplikasi ini bisa digunakan pada perangkat Smartphone android. Gambar 5 sampai dengan Gambar 9 merupakan hasil tampilan Media Pembelajaran "Belajar Tajwid Metode Asysyafi' 'i” ini dari setiap tampilan:

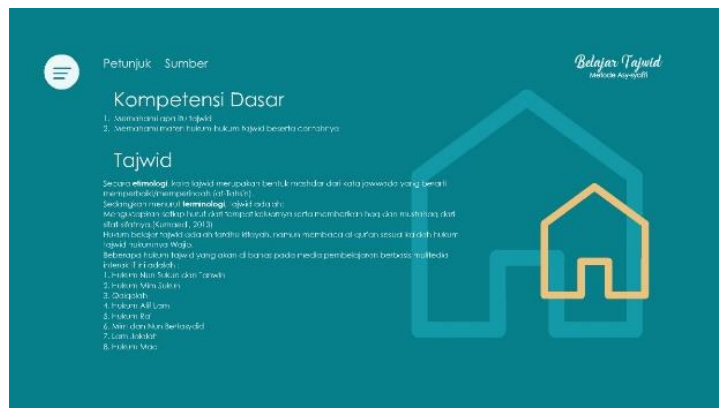

Gambar 5. Tampilan Halama Utama Aplikasi

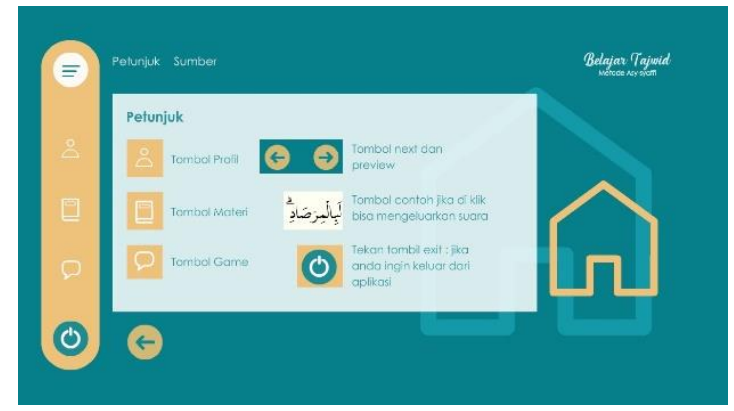

Gambar 6. Tampilan Menu Petunjuk

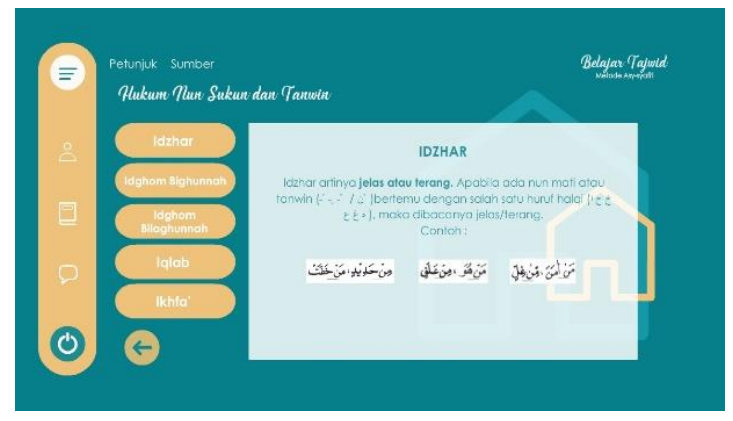

Gambar 7. Tampilan Materi Beserta Contoh

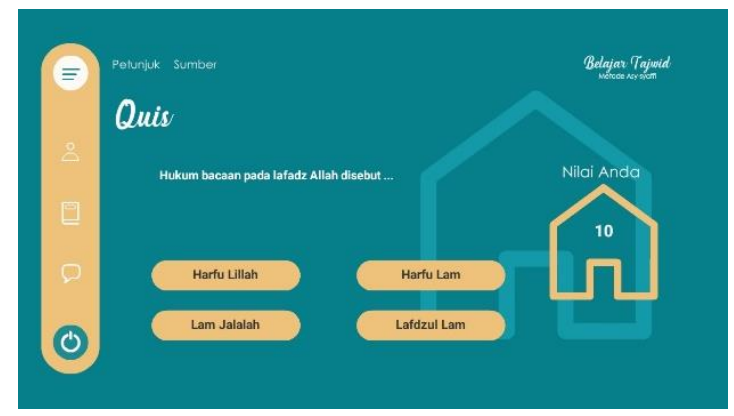

Gambar 8. Tampilan Game/Quiz 


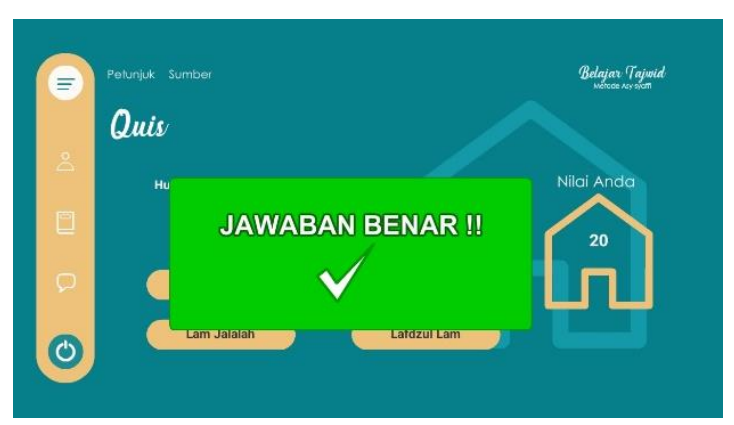

Gambar 9. Tampilan Ketika Jawaban yang Dipilih Benar

Media pembelajaran yang dibuat oleh penulis berukuran $17 \mathrm{Mb}$ menggunakan format jenis publisher Air SDK 32 dengan output berupa file *apk, yang bisa diinstal di smartphone android. Media pembelajaran ini telah siap untuk didistribusikan kepada masyarakat umum sebagai objek penelitian dari media pembelajaran Hukum Tajwid.

Dalam pendistribusian kuesioner dan aplikasi, penulis menggunakan cara broadcast link g-form kuesioner dan link $g$-drive aplikasi. Responden mendownload dulu aplikasi pada link $g$ drive yang tersedia setelah itu meng-install-nya pada perangkat android masing-masing. Setelah menggunaka aplikasi tersebut, barulah responden dapat mengisi kuesioner pada link g-form.

\section{Data Hasil Pengujian Alfa}

Pengujian alfa dilakukan untuk mengetahui kelayakan aplikasi media pembelajaran yang di buat. Penilaian kelayakan aplikasi dilakukan oleh 4 orang ahli di bidang multimedia, dengan melihat dari latar belakang jurusan pendidikan dan pekerjaannya di bidang animasi ataupun multimedia. Para ahli berasal dari Palembang dan Parepare.

TABEL X. HASIL PENGUJIAN ALFA

\begin{tabular}{|c|c|c|c|c|c|c|}
\hline \multirow[b]{2}{*}{ No } & \multirow[b]{2}{*}{ Aspek yang dinilai } & \multicolumn{5}{|c|}{ Pilihan Jawaban } \\
\hline & & & & $\mathrm{C}$ & B & $\begin{array}{l}\text { S } \\
\text { B }\end{array}$ \\
\hline 1 & $\begin{array}{l}\text { Tampilan layar pada media } \\
\text { pembelajaran menarik dari segi } \\
\text { warna dan teks }\end{array}$ & & & & 3 & 1 \\
\hline 2 & $\begin{array}{l}\text { Kesesuaian musik pengiring } \\
\text { dan kualitas audio pada media } \\
\text { pembelajaran }\end{array}$ & & & 1 & 2 & 1 \\
\hline 3 & $\begin{array}{l}\text { Ketepatan pemilihan bahasa } \\
\text { pada media pembelajaran }\end{array}$ & & & & 1 & 3 \\
\hline 4 & $\begin{array}{l}\text { Kejelasan navigasi, kecepatan } \\
\text { dan ketepatan program pada } \\
\text { media pembelajaran }\end{array}$ & & & 2 & 2 & \\
\hline 5 & 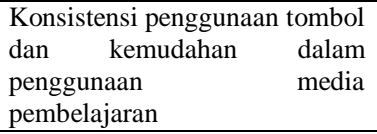 & & 1 & & 2 & 1 \\
\hline
\end{tabular}

2. Data Hasil Pengujian Beta

Data pengujian beta ialah para responden yang terdiri dari 40 masyarakat umum yang berusia lebih dari 14 tahun. Dengan tujuan aplikasi media pembelajaran dapat menyajikan materi dan contoh yang dapat mengedukasi masyarakat tentang hukum tajwid.

TABEL XI. HASIL PENGUJIAN BETA

\begin{tabular}{|c|c|c|c|c|c|c|}
\hline \multirow[b]{2}{*}{ No } & \multirow[b]{2}{*}{ Aspek yang dinilai } & \multicolumn{5}{|c|}{ Pilihan Jawaban } \\
\hline & & $\begin{array}{l}\mathbf{S} \\
\mathbf{K} \\
\mathbf{B}\end{array}$ & $\begin{array}{l}\mathbf{K} \\
\mathbf{B}\end{array}$ & $\mathbf{C}$ & B & SB \\
\hline 1 & $\begin{array}{l}\text { Tampilan layar pada media } \\
\text { pembelajaran menarik dari } \\
\text { segi warna dan teks }\end{array}$ & & & & 7 & 33 \\
\hline 2 & $\begin{array}{lr}\text { Kesesuaian } & \text { musik } \\
\text { pengiring dan } & \text { kualitas } \\
\text { audio pada } & \text { media } \\
\text { pembelajaran } & \end{array}$ & & & 5 & 10 & 25 \\
\hline 3 & $\begin{array}{l}\text { Kejelasan uraian materi dan } \\
\text { pemberian contoh pada } \\
\text { media pembelajaran }\end{array}$ & & & & 13 & 27 \\
\hline 4 & $\begin{array}{l}\text { Setelah menggunakan } \\
\text { media pembelajaran ini } \\
\text { anda mengetahui tentang } \\
\text { hukum-hukum tajwid }\end{array}$ & & & & 9 & 31 \\
\hline 5 & $\begin{array}{l}\text { Materi yang di sampaikan } \\
\text { pada media pembelajaran } \\
\text { ini mudah di pahami }\end{array}$ & & & & 9 & 31 \\
\hline
\end{tabular}

\section{B. Pembahasan}

Setelah semua proses pada tahap perancangan dilakukan, maka dihasilkan suatu produk berupa aplikasi media pembelajaran dengan judul Belajar Tajwid Metode Asy-syafi'i dengan format berupa file *apk. Aplikasi media pembelajaran ini berukuran $17 \mathrm{Mb}$ dan bisa diinstal pada smartphone android. Pada tahap pengujian, setelah didapatkan hasil analisis data dan analisis pengujian dari responden alfa dan beta, maka dapat diketahui kelayakan Aplikasi media pembelajaran Hukum Tajwid ini untuk dapat didistribusikan kepada masyarakat. Berikut merupakan hasil analisis data pengujian alfa dan pengujian beta

\section{Hasil analisis pengujian responden Alfa}

Analisis hasil pengujian alfa didapatkan berdasarkan pertanyaan yang diberikan kepada responden terkait tampilan dari aplikasi media pembelajaran Hukum Tajwid yang telah di distribusikan kepada responden. 


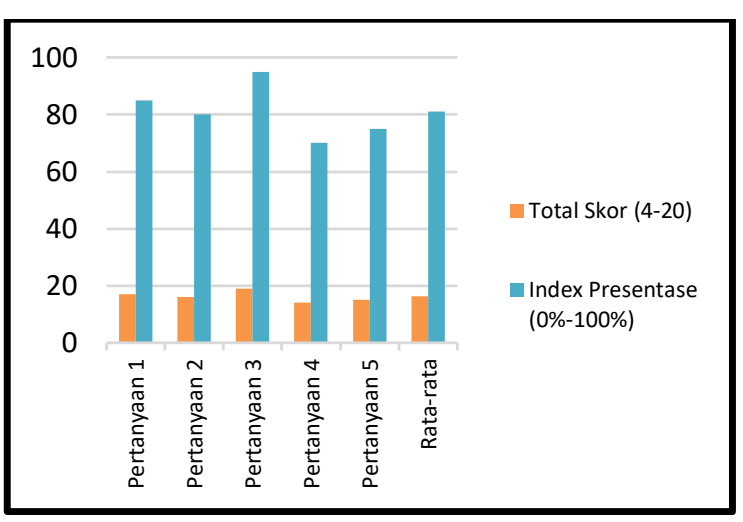

Gambar 10. Diagram Hasil Analisis Pengujian Responden Alfa

Berdasarkan hasil dari penilaian dan analisis terhadap aplikasi media pembelajaran yang telah ditampilkan kepada responden alfa atau ahli. Aplikasi media pembelajaran Hukum Tajwid, bila di rata-ratakan mendapatkan skor 16,2 dan Indeks Persentase $81 \%$, berada di kategori "Sangat Baik". Maka aplikasi media pembelajaran ini layak secara kualitas aplikasi layak untuk didistribusikan kepada masyarakat.

2. Hasil analisis pengujian responden Beta

Analisis hasil pengujian beta didapatkan berdasarkan pertanyaan yang diberikan kepada responden terkait isi, baik materi maupun contoh yang diberikan pada aplikasi media pembelajaran yang telah digunakan oleh responden.

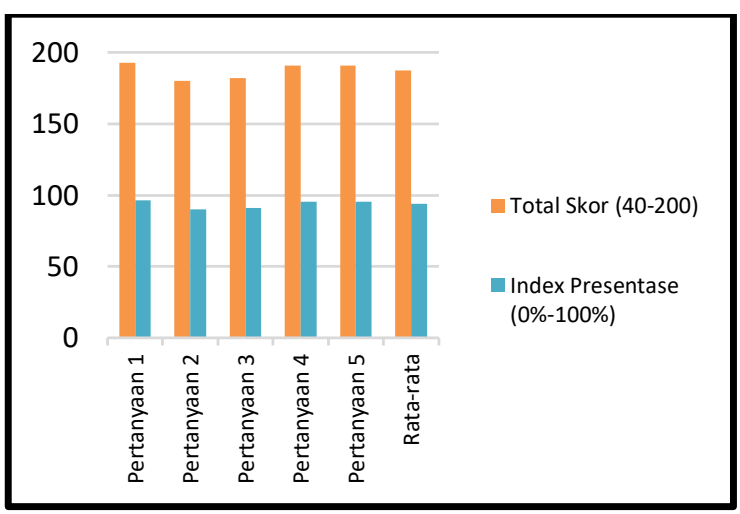

Gambar 11. Diagram Hasil Analisis Pengujian Responden Beta

Berdasarkan hasil dari penilaian dan analisis terhadap aplikasi media pembelajaran yang telah ditampilkan kepada responden beta sebagai masyarakat yang menggunakan aplikasi. Aplikasi media pembelajaran Hukum Tajwid, bila di rataratakan mendapatkan skor 187,4 dan indeks persentase 93,7\% berada di kategori "Sangat Baik". Maka kualitas materi dan pemberian contoh dalam media pembelajaran ini dapat dipahami oleh masyarakat.

Selain dari pertanyaan-pertanyaan yang ditanyakan, dalam kuesioner yang disebar penulis juga memberikan kolom saran dan komentar pada kuesioner tersebut. Banyak responden yang berkomentar bahwa aplikasi media pembelajaran ini sangat bermanfaat bagi mereka terlebih pemakaiannya yang praktis dapat digunakan dimanapun dan kapanpun membuat mereka mudah menggunakannya untuk mempelajari ilmu tajwid.

\section{KESIMPULAN DAN SARAN}

\section{A. Kesimpulan}

Berdasarkan perancangan dan realisasi aplikasi media pembelajaran yang telah dikerjakan, maka dapat diambil beberapa kesimpulan yaitu pembuatan media pembelajaran ini menggunakan komponen 2D. Selanjutnya komponen 2D tersebut disusun melalui penyusunan layout dan pemberian coding untuk mengaktifkan fungsi tombol pada aplikasi sehngga pengguna mudah untuk menggunakannya.

Berdasarkan hasil uji kuesioner terhadap responden, maka dapat disimpulkan responden setuju bahwa:

1. Materi dan contoh yang disajikan pada aplikasi ini mudah dipahami dan mudah dimengerti. Hal ini dibuktikan dari indeks persentase pada hasil pengujian responden sebesar $91 \%$, dan berada dalam kategori "Sangat Baik".

2. Aplikasi ini berkualitas dari segi isi hal ini ditandai setelah menggunakan aplikasi ini, pengguna mengetahui tentang hukum-hukum tajwid. Hal ini dibuktikan dengan indeks persentase dari hasil pengujian responden sebesar 95,5\%, dan berada dalam kategori "Sangat Baik".

3. Aplikasi ini mudah dipahami dan digunakan oleh pengguna $\mathrm{Hal}$ ini dibuktikan dengan indeks persentase dari hasil pengujian responden sebesar 95,5\%, dan berada dalam kategori "Sangat Baik".

4. Aplikasi ini menarik dari segi tampilan secara keseluruhan dari aplikasi. Hal ini dibuktikan dengan indeks persentase dari hasil pengujian responden sebesar 96,5\%, dan berada dalam kategori "Sangat Baik".

5. Aplikasi ini menarik dari segi audio. Hal ini dibuktikan dengan indeks persentase dari hasil pengujian responden sebesar $90 \%$, dan berada dalam kategori "Sangat Baik".

6. Aplikasi ini dapat diinstall dan digunakan pada Smartphone android.

B. Saran

Penulis menyadari masih banyak kekurangan dalam proses perancangan aplikasi media pembelajaran yang penulis buat. Untuk itu penulis memberikan beberapa saran diantaranya: 
1. Pada pengembangan selanjutnya, penulis berharap pengisi voice over pada contoh materi merupakan native speaker agar contoh yang diberikan sesuai dengan pelafalan Bahasa Arab yang benar.

2. Sebaiknya pada pembuatan aplikasi media pembelajaran selanjutnya dapat ditambahkan kejelasan dari fungsi tombol navigasi, dengan cara menambahkan menu petunjuk pada media pembelajaran yang dibuat.

3. Pengembang selanjutnya dapat menambahkan isi materi dengan pembahasan lebih luas lagi, mengingat lingkup pelajaran hukum tajwid masih banyak yang belum dibahas oleh penulis.

\section{REFERENSI}

[1] Maiyurita, Z. K. Simbolon, and N. Prihatin, “Aplikasi Pembelajaran Tajwid Menggunakan Linear Conguent Method Berbasis Android," J. Info Media, vol. 1, no. 1, 2016.

[2] A. Sarifudin and N. Ernawati, "Pengaruh Penggunaan Metode Yanbu'a Terhadap Kemampuan Membaca Alquran Santri Di Pondok Pesantren Al-Badar Kecamatan Pamijahan Bogor," J. Edukasi Islam. J. Pendidik. Islam, vol. 9, no. 2, pp. 189-208, 2020.

[3] W. Wardiana, "Perangkat Ajar Interaktif Tentang Hukum Tajwid Untuk Pembacaan Al - Qur ' an," INKOM, pp. 16-20, 2015.

[4] Rohani, Diktat Media Pembelajaran. Sumatera Utara: Universitas Islam Negeri Sumatera Utara, 2019.

[5] G. Mawardi, T. Iriani, and Daryati, "Pengembangan Media Pembelajaran Berbasis Multimedia Pada Mata Kuliah Kompetensi Pembelajaran Pokok Materi Keterampilan Dasar Mengajar," J. Pensil Pendidik. Tek. Sipil, vol. 1, pp. 24-30, 2019.

[6] Wahyuni, "Pelaksanaan Metode Asy-syafi'i Dalam Meningkatkan Membaca Al-qur'an Siswa Di Sekolah Dasar Negeri 09/IV Kota Jambi," Universitas Islam Negeri Sulthan Thaha Saifuddin Jambi, 2020.

[7] N. Anggraeni, "Pengembangan Media Pembelajaran Berbasis Multimedia Interaktif Menggunakan Adobe Flash CS5 Untuk Smk Kelas Xi Kompetensi Keahlian Administrasi Perkantoran Pada Kompetensi Dasar Menguraikan Sistem Informasi Manajemen," Universitas Negeri Yogyakarta, 2015.

[8] I. D. Kurniawati and S. Nita, "Media Pembelajaran Berbasis Multimedia Interaktif untuk Meningkatkan Pemahaman Konsep Mahasiswa," J. Comput. Inf.
Technol., vol. 1, no. 2, pp. 68-75, 2018.

[9] Haryuningsih, "Perancangan Aplikasi Panduan Belajar Mengenal Ilmu Tajwid Berbasis Android," $J$ Perencanaan, Sains, Teknol. dan Komput., vol. 2, no. 1, pp. $148-159,1981$

[10] A. Y. Kurnaedi, Tajwid Lengkap Asy-syafi'i, 6th ed. Jakarta: Pustaka Imam Ash-shafi'i, 2018.

[11] A. H. Ishaq and R. Nawawi, "Ilmu Tajwid Dan Implikasinya Terhadap Ilmu Qira'ah," $Q O F$, vol. 1, no. 1, pp. 15-37, 2017.

[12] R. Suryani, H. Saputra, and A. Sutrisman, "Implementasi Animasi 2D Pada Iklan Layanan Masyarakat Ebagai Sosialisasi Penyakit DBD," $J$. Rekam, vol. 15, no. 2, pp. 153-166, 2019.

[13] I. A. Ridlo, "Pedoman Pembuatan Flowchart," Academia.Edu, p. 14, 2017.

[14] E. Nugroho, Prinsip-prinsip Menyusun Kuesioner, 1st ed. Malang: UB Press, 2018.

[15] H. Anisyah, H. Saputra, and Mustaziri, "Penerapan Video Animasi Motion Graphic Tentang Pembuatan Kartu Identitas Anak di Kecamatan Sukarami," J. Multinetics, vol. 5, no. 2, pp. 94-100, 2019. 